\title{
Opioid Antagonism of Cannabinoid Effects: Differences between Marijuana Smokers and Nonmarijuana Smokers
}

\author{
Margaret Haney*,' \\ 'Department of Psychiatry, New York State Psychiatric Institute, College of Physicians and Surgeons of Columbia University, New York, NY, USA
}

In non-human animals, opioid antagonists block the reinforcing and discriminative-stimulus effects of $\Delta^{9}$-tetrahydrocannabinol (THC), while in human marijuana smokers, naltrexone $(50 \mathrm{mg})$ enhances the reinforcing and subjective effects of THC. The objective of this study was to test a lower, more opioid-selective dose of naltrexone $(12 \mathrm{mg})$ in combination with THC. The influence of marijuana-use history and sex was also investigated. Naltrexone $(0,12 \mathrm{mg})$ was administered 30 min before oral THC $(0-40 \mathrm{mg})$ or methadone ( 0 $10 \mathrm{mg}$ ) capsules, and subjective effects, task performance, pupillary diameter, and cardiovascular parameters were assessed in marijuana smoking (Study I; $n=22$ ) and in nonmarijuana smoking (Study 2; $n=21$ ) men and women. The results show that in marijuana smokers, low-dose naltrexone blunted the intoxicating effects of a low THC dose $(20 \mathrm{mg})$, while increasing ratings of anxiety at a higher THC dose $(40 \mathrm{mg})$. In nonmarijuana smokers, low-dose naltrexone shifted THC's effects in the opposite direction, enhancing the intoxicating effects of a low THC dose $(2.5 \mathrm{mg})$ and decreasing anxiety ratings following a high dose of THC $(10 \mathrm{mg})$. There were no sex differences in these interactions, although among nonmarijuana smokers, men were more sensitive to the effects of $\mathrm{THC}$ alone than women. To conclude, a low, opioid-selective dose of naltrexone blunted THC intoxication in marijuana smokers, while in nonmarijuana smokers, naltrexone enhanced THC intoxication. These data demonstrate that the interaction between opioid antagonists and cannabinoid agonists varies as a function of marijuana use history.

Neuropsychopharmacology (2007) 32, I39 | - |403. doi: I 0. I 038/s.npp. I 30 I243; published online 8 November 2006

Keywords: naltrexone; methadone; THC

\section{INTRODUCTION}

Cannabinoid receptors (CB1) and mu opioid receptors are both G-protein-coupled receptors with overlapping neuroanatomical localization and physiological function (see Navarro et al, 2001). A variety of non-human animal data demonstrate a compelling bi-directional interaction between endogenous cannabinoids and the endogenous opioid peptides (see Manzanares et al, 1999). Cannabinoid effects, mediated at the CB1 receptor, can be modulated by opioidergic antagonists binding to mu, delta, and kappa opioid receptors. Correspondingly, opioid effects can be modulated by CB1 antagonists. The precise nature of this interaction differs as a function of endpoint measured (eg, analgesia, dependence, reinforcement) and the species tested.

\footnotetext{
*Correspondence: Dr M Haney, New York State Psychiatric Institute, College of Physicians and Surgeons of Columbia University, I05 I Riverside Dr., Unit 120, New York, NY 10032, USA. Tel: + I 212543 6539, Fax: + | 212543 599|, E-mail:mh235@columbia.edu

Received 25 July 2006; revised 12 September 2006; accepted 19 September 2006

Online publication: 22 September 2006 at http://www.acnp.org/ citations/Npp092206060493/default.pdf
}

With respect to cannabinoid dependence, the opioid antagonist, naloxone: (1) prevented the development of cannabinoid dependence when coadministered with $\Delta^{9}$ tetrahydrocannabinol (THC), the primary psychoactive component of marijuana (Tulunay et al, 1981), and (2) precipitated symptoms of withdrawal following chronic THC administration (Kaymakcalan et al, 1977; Hirschhorn and Rosencrans, 1974; Navarro et al, 1998, 2001) in rats. By contrast, opioid antagonists did not precipitate symptoms of withdrawal in cannabinoid-dependent pigeons (McMillan et al, 1971), mice (Lichtman et al, 2001), monkeys (Beardsley et al, 1986), or humans (Haney et al, 2003). However, THC's dependence-producing effects were decreased in a genetic mouse strain lacking the opioid precursor, preproenkephalin (Valverde et al, 2000), and in a strain lacking mu and delta opioid receptors (Castãné et al, 2003; Lichtman et al, 2001), suggesting a possible opioid contribution to cannabinoid dependence. Yet, the precise opioid contribution appears to vary across species.

With regard to cannabinoid reinforcement, studies in rats (Braida et al, 2001; Navarro et al, 2001), mice (Navarro et al, 2001), and monkeys (Justinova et al, 2004) demonstrate that opioid receptor antagonists decrease self-administration of cannabinoid agonists. In rats, opioid antagonists also decrease: (1) cannabinoid-induced reinstatement of 
extinguished cannabinoid self-administration (Spano et al, 2004), (2) THC-enhancement of intracranial self-stimulation (Chen et al, 1991), (3) THC's discriminative-stimulus effects (Solinas et al, 2004b), and (4) THC-induced dopamine release in the nucleus accumbens (French, 1997; Chen et al, 1990, 1991; Casteñada et al, 1991; Tanda et al, 1997; Gessa et al, 1998), hypothesized to be one of the neural sites mediating drug reinforcement (Di Chiara, 1995).

Yet, in humans, opioid antagonists have not been shown to decrease any cannabinoid effect. For example, the opioid antagonist, naltrexone, did not alter cannabinoid analgesia (Greenwald and Stitzer, 2000), and did not antagonize the subjective, reinforcing or physiological effects of THC in human marijuana smokers (Wachtel and de Wit, 2000; Haney et al, 2003). In fact, the intoxicating effects of a high dose of THC $(30 \mathrm{mg})$ were enhanced rather than antagonized by naltrexone in marijuana smokers (Haney et al, 2003).

What factors, other than species, might account for the different results obtained in human and non-human animals? One possibility is that the dose of naltrexone given to humans $(50 \mathrm{mg})$ was not selective for opioid receptors, but acted at nonopioid sites, such as the $\mathrm{GABA}_{\mathrm{A}}$ receptor to increase the effects of THC (eg, Dingledine et al, 1978; Gewiss et al, 1994; Svensson et al, 2000). Thus, the objective of Study 1 was to determine if a low, more opioidselective dose of naltrexone $(12 \mathrm{mg})$ would antagonize THC's effects in current marijuana smokers.

Another possibility is that chronic marijuana use alters the response to opioid antagonists in humans. The cannabinoid reinforcement studies described above were conducted in laboratory animals that were not chronically exposed to cannabinoids. In naïve laboratory animals, acute THC administration increases extracellular concentrations of endogenous opioid peptides in brain sites involved in drug reinforcement: the ventral tegmental area (VTA) and nucleus accumbens (Solinas et al, 2004b; Valverde et al, 2001). Yet, chronic cannabinoid exposure produces tolerance, which in animal models is associated with both downregulation of $\mathrm{CB} 1$ receptors, desensitization of $\mathrm{CB} 1$ receptor-mediated G-protein activation and decreased THC-induced dynorphin release (Mason et al, 1999; Martin et al, 2004; Corchero et al, 1999). Further, chronic cannabinoid administration in rats increases gene expression for opioid peptide precursors in brain sites regulating pain, reinforcement, and locomotor activity (Sim et al, 1996a, b; Corchero et al, 1997, 1999; Manzanares et al, 1998), increases $\mathrm{mu}$ opioid receptor binding in the lateral thalamus and periaqueductal gray, and increases opioidstimulated G-protein binding in the nucleus accumbens (Viganò et al, 2005). Chronic cannabinoid administration also alters the behavioral effects of opioids in rats: increasing opioid-induced locomotor activity as well as opioid self-administration (Lamarque et al, 2001; Cadoni et al, 2001; Norwood et al, 2003; Solinas et al, 2004a). Thus, the objective of Study 2 was to determine the effect of a low naltrexone dose $(12 \mathrm{mg})$ in combination with oral THC in individuals with no history of chronic marijuana use.

An additional objective for both studies was to determine if sex influences the interaction between naltrexone and THC. In the preclinical studies of cannabinoid reinforcement, only male mice, rats, and monkeys were tested, and the participants in our earlier human studies were also predominantly male (81\%; Haney et al, 2003). Yet, smoked marijuana produces larger cardiovascular and subjective effects in men than women (Penetar et al, 2005), so it may be that a sex difference in naltrexone's effects on THC exists as well.

\section{METHODS}

\section{Study 1: Marijuana Smokers}

Participants. Table 1 describes the demographic information of the healthy male $(n=10)$ and female $(n=12)$ research volunteers who participated in the studies. Five additional male volunteers and eight additional female volunteers began but discontinued the Study 1 for not adhering to protocol $(n=7)$ or because they did not like the medication effects $(n=6)$. Before study onset, participants provided a detailed drug and medical history, received complete medical and psychiatric evaluations, and signed consent forms detailing all aspects of the research. To be eligible for the study, volunteers had to: be 21-45 years of age, currently smoke marijuana, not be dependent on other drugs of abuse (other than nicotine), and pass the medical and psychiatric criteria for participation. Participants were

Table I Demographic Characteristics of Study Participants

\begin{tabular}{|c|c|c|c|c|}
\hline & \multicolumn{2}{|c|}{ Marijuana smokers (Study I) } & \multicolumn{2}{|c|}{ Nonmarijuana smokers (Study 2) } \\
\hline & Male & Female & Male & Female \\
\hline Age & $25.6 \pm 3.3$ & $27.0 \pm 5.8$ & $29.8 \pm 5.7$ & $29.5 \pm 6.7$ \\
\hline Race/ethnicity (Blk/Wht/Hisp) & $6 / 3 / 1$ & $6 / 3 / 3$ & $2 / 8 / 1$ & $4 / 6 / 0$ \\
\hline Education & $13.7 \pm 1.7$ & $13.3 \pm 1.8$ & $15.8 \pm 1.7$ & $16.6 \pm 1.6$ \\
\hline MJ use (\# days/week) & $6.4 \pm 1.2$ & $5.7 \pm 1.7$ & NA & NA \\
\hline MJ cigarettes/day & $5.2 \pm 3.7^{*}$ & $2.3 \pm 1.4$ & NA & NA \\
\hline MJ (\# years smoked) & $6.9 \pm 5.1$ & $8.6 \pm 7.5$ & NA & NA \\
\hline Cigarettes smokers (\#) & 6 & 8 & 4 & 1 \\
\hline Cigarettes/day & $11.0 \pm 7.7$ & $10.3 \pm 8.0$ & $5.4 \pm 6.6$ & $15 \pm 0$ \\
\hline
\end{tabular}

Note: Data are presented as means $( \pm S D)$ or as frequency. Blk =Black; Wht = White; Hisp = Hispanic; MJ = marijuana. NA $=$ not applicable. ${ }^{*} p<0.05$. 
within accepted weight ranges for their height (body mass index $<30 \mathrm{~kg} / \mathrm{m}^{2}$ ).

Participants were instructed that the study objective was to determine the effects of commonly prescribed or overthe-counter medications in marijuana smokers. They were given an 8-item list of specific antidepressants, opiate antagonists, antiemetics, and analgesics, and were told that they could receive any medication on that list or they could receive placebo. All procedures were approved by the Institutional Review Board of the New York State Psychiatric Institute and were in accord with the Declaration of Helsinki.

Design and procedures. Participants were outpatients at the New York State Psychiatric Institute for eight experimental sessions over the course of 3-4 weeks. Experimental sessions were separated by at least $48 \mathrm{~h}$ in order prevent carryover effects from session-to-session. Before study onset, participants received one to two practice sessions on the computerized tasks; no capsules were administered on practice sessions.

For experimental sessions, methadone (10 mg Dolophine, Roxane Laboratories Inc.), THC (20, $40 \mathrm{mg}$ Marinol, Unimed Pharmaceuticals Inc.), and placebo were each given in combination with each dose of naltrexone $(0,12 \mathrm{mg}$ ReVia, Dupont Pharma); medications were packaged into size 00 opaque capsules with lactose filler by the New York State Psychiatric Research Pharmacy. This dose of naltrexone has been shown to function as an opioid antagonist in humans (Walsh et al, 1996). Methadone, an opiate with a similar time-course and half-life as THC, was tested as a positive control for assessing the effects of naltrexone. The order of dosing was randomized, with the exception that at least 6 days elapsed before naltrexone followed the methadone/placebo naltrexone conditions to avoid precipitating opioid withdrawal. Naltrexone preceded the second capsule administration by $30 \mathrm{~min}$, so naltrexone levels would peak when THC and methadone's behavioral effects peak (Wall et al, 1981).

Experimental sessions. Experimental sessions began at 0900 hours and lasted until 1600 hours. Participants were instructed to not eat breakfast before the session and to refrain from using illicit drugs (other than possibly marijuana) for the duration of the study. Alcohol use was to be excluded $24 \mathrm{~h}$ before or following a laboratory session. Marijuana use the morning of the session was also prohibited. Urine was tested for the presence of drug metabolites (cocaine, opiates, methamphetamine, amphetamine, cannabinoids) during screening and at the beginning of each session. A breath alcohol test was also conducted at the beginning of each session. Sessions were canceled if there was evidence of illicit drug use (other than marijuana) or alcohol/marijuana use that morning.

Participants were served a standardized breakfast (eg, bagel or cereal, juice, coffee/tea). Following breakfast, baseline cardiovascular and pupillary measures, a balance task (the total number of seconds participants could balance for a maximum of $30 \mathrm{~s}$ on each foot; Evans et al, 1994), subjective-effects questionnaires and performance tasks were completed. Naltrexone administration was followed
$30 \mathrm{~min}$ later by the administration of placebo, THC, or methadone. The participant and study staff were blind to capsule content. Cardiovascular, pupillary, subjectiveeffects and psychomotor performance measures were completed at specified time points $30-60 \mathrm{~min}$ following the second capsule administration. The Capsule Rating Form was completed at 90-180 min intervals following the second capsule administration. Participants were given an immediate word recall test $120 \mathrm{~min}$ following the second capsule and a delayed word recall and recognition test $330 \mathrm{~min}$ following the second capsule administration. Cigarette smokers were permitted to smoke at predetermined intervals throughout the experimental day, in order to minimize the likelihood of nicotine withdrawal symptoms. At the end of each session, participants were required to pass a field sobriety and balance task. If behavior was impaired, participants remained in the laboratory until the drug effects subsided, or they were sent home in a prepaid taxi. Participants were provided subway fare at the end of each session, and were instructed not to drive a car for at least $8 \mathrm{~h}$.

Subjective-effects questionnaires and performance tasks.

Visual analog scales: Participants completed a 50-item visual analog scale (VAS), which consisted of a 100-mm line anchored with 'not at all' at the left end and 'extremely' at the right end, labeled with a range of moods and physical symptoms (described by Haney et al, 1999).

Capsule Rating Form: Participants completed a 5-item VAS, rating the strength of the drug effect, good effect, bad effect, willingness to take drug again, and drug liking. In addition, participants were asked to indicate whether they thought the drug was most like a placebo, sedative, or stimulant.

Performance battery: Participants completed a 5-item task battery, consisting of a 3-min digit-symbol substitution task (DSST), a 3-min repeated acquisition task, a 10-min divided attention task (DAT), a 10-min rapid information task (RIT), and immediate and a delayed digit-recall task. The battery measures various aspects of learning, memory, vigilance, and psychomotor ability (see Foltin et al, 1996 for a description of the tasks). Participants were instructed to complete each task as quickly and as accurately as possible.

Word recall/recognition task: To assess immediate free recall, participants studied a list of 12 common nouns (four to eight characters each) for $90 \mathrm{~s}$, and then had to write as many words as they could remember. To assess delayed free recall, participants repeated this task 210 min later. This was followed by a recognition test, in which participants had to identify the 12 words shown earlier from a list containing 48 words (Evans et al, 1998).

Physiological measures: Heart rate and blood pressure were measured using a Sentry II vital signs monitor (Model 6100: NBS Medical Services, Costa Mesa, CA). A specially modified Polaroid camera with a close-up lens $(\times 2$ magnification) was used to take pupil photographs (Comer et al, 1998). 
Data analysis. Repeated measures analyses of variance (ANOVA) with planned comparisons were used to determine if naltrexone modulates the effect of THC or methadone on subjective-effects ratings, task performance, drug-effects ratings, pupil diameter, and cardiovascular measures. In order to reduce the number of dependent variables tested, the 50 subjective-effects ratings were subjected to a cluster analysis which yielded seven clusters; items within one cluster were predictive of changes in other items in that cluster, but did not predict changes in other clusters. The analysis yielded seven clusters: 'high,' consisting of two items (high, good drug effect); 'miserable,' consisting of three items (miserable, depressed, irritable); 'tired,' consisting of six items (tired, sedated, sleepy, unmotivated, clumsy, withdrawn), 'on edge,' consisting of five items (on edge, jittery, anxious, restless, stimulated); 'bad effect,' consisting of eight items (bad drug effect, dizzy, upset stomach, stomach pain, nausea, blurred vision, headache, chills, heart-pounding); 'content,' consisting of seven items (content, mellow, alert, talkative, self-confident, energetic, social); and 'confused,' consisting of three items (confused, forgetful, cannot concentrate). Cluster ratings were derived by taking the mean of each item in the cluster.

There were three within-group factors (medication (placebo, $20 \mathrm{mg}$ THC, $30 \mathrm{mg}$ THC, $10 \mathrm{mg}$ methadone), naltrexone $(0,12 \mathrm{mg})$, and time within session (baseline measures through $360 \mathrm{~min}$ )) and one between-groups factor (sex). In order to determine the effects of naltrexone for each drug condition, four planned comparisons were completed for each measure: time course data collected after capsule administration were averaged, and a comparison between the active and placebo naltrexone pretreatment condition was made for placebo, THC (20 mg), THC $(30 \mathrm{mg})$, and methadone $(10 \mathrm{mg})$. There was no significant interaction between sex and naltrexone dose, or the combination of sex, medication, and naltrexone dose for any measure, so data from males and females were combined. Huynh-Feldt corrections were used, when appropriate. $p$-Values less than 0.05 were considered statistically significant.

\section{RESULTS}

\section{Study 1: Marijuana Smokers}

Demographic characteristics. As shown in Table 1, men smoked over twice the number of marijuana cigarettes per day than women $(p<0.05)$. There were no other significant sex differences in demographic characteristics.

Pupil diameter. Figure 1, which shows the effects of methadone on pupil diameter as a function of time within session and naltrexone dose, demonstrates that methadone decreased pupil size time-dependently, and naltrexone reversed these effects $(p<0.01)$.

Subjective-effects ratings. Figure 2, which shows the effects of placebo, THC, and methadone as a function of time within session and naltrexone dose, demonstrates that naltrexone had intrinsic effects that peaked shortly (30$90 \mathrm{~min}$ ) after capsule administration: under placebo conditions, naltrexone pretreatment tended to increase cluster

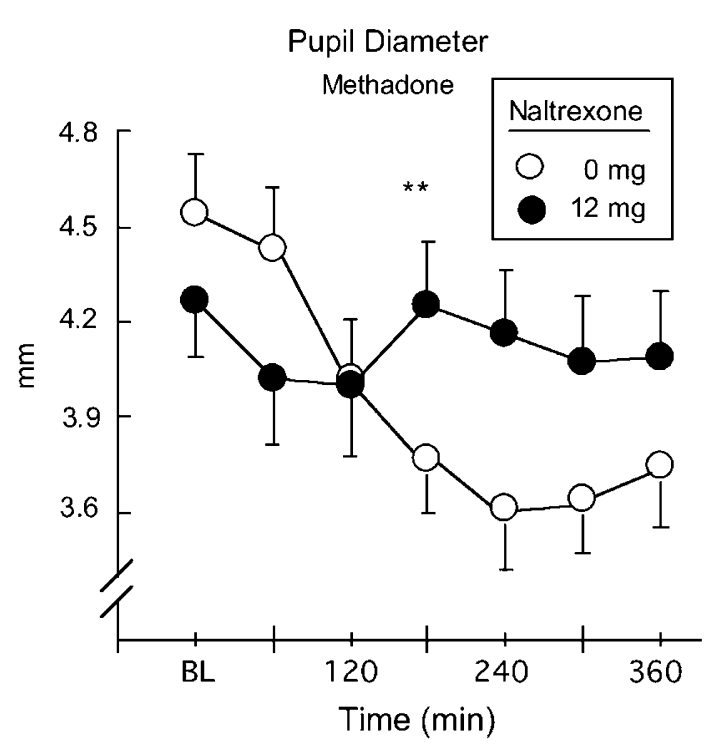

Figure I Methadone effects on pupil diameter as a function of time and naltrexone dose in Study I (marijuana smokers). Asterisks denote a significant difference between active and placebo naltrexone on data averaged over the 60-360 min following methadone (I0 mg) administration $(* * p<0.01$ ). Error bars represent standard error of the mean (SEM).

ratings of 'high' $(p<0.07)$. Table 2 , which shows cluster ratings averaged over time after capsule administration, demonstrates that naltrexone alone significantly increased ratings of 'tired' (Table 1: $p<0.05$ ).

THC produced dose- and time-dependent increases in cluster ratings of 'high,' 'on edge' and 'tired' that peaked between 120 and $180 \mathrm{~min}$ postcapsule ingestion. Naltrexone significantly $(p<0.01)$ decreased the effects of the lower THC dose $(20 \mathrm{mg})$ on ratings of 'high' (Figure 2). At the larger THC dose $(40 \mathrm{mg})$, naltrexone significantly increased ratings of 'on edge' (Figure 2) and 'tired' (Table 1: $p<0.01$ ).

Methadone's effects also peaked 120-180 min after capsule administration. Methadone increased ratings of 'high.' Naltrexone did not alter this effect, but significantly increased ratings of 'tired' following methadone administration (Table 1: $p<0.05$ ).

Capsule Rating Form. Figure 3 portrays mean capsule ratings of placebo, THC, and methadone as a function of naltrexone dose; ratings were obtained $90-180 \mathrm{~min}$ following capsule administration. Naltrexone alone had no significant effect. THC increased ratings of capsule strength, liking, and bad drug effect compared to placebo. Compared to placebo, naltrexone significantly decreased ratings of capsule strength and capsule liking following the low THC dose $(20 \mathrm{mg})$. Methadone increased ratings of bad drug effect and naltrexone reversed this effect $(p<0.05)$.

Performance effects. Naltrexone alone had no significant effect on performance. THC also did not produce dose- or time-dependent effects on task performance (Figure 2; Table 2). However, naltrexone worsened performance on the DSST following the high dose $(40 \mathrm{mg}$ ) of THC (Figure 2, $p<0.05)$. Accurate performance on the Digit Recall Task following THC $(40 \mathrm{mg})$ administration was also worsened by naltrexone compared to placebo. 

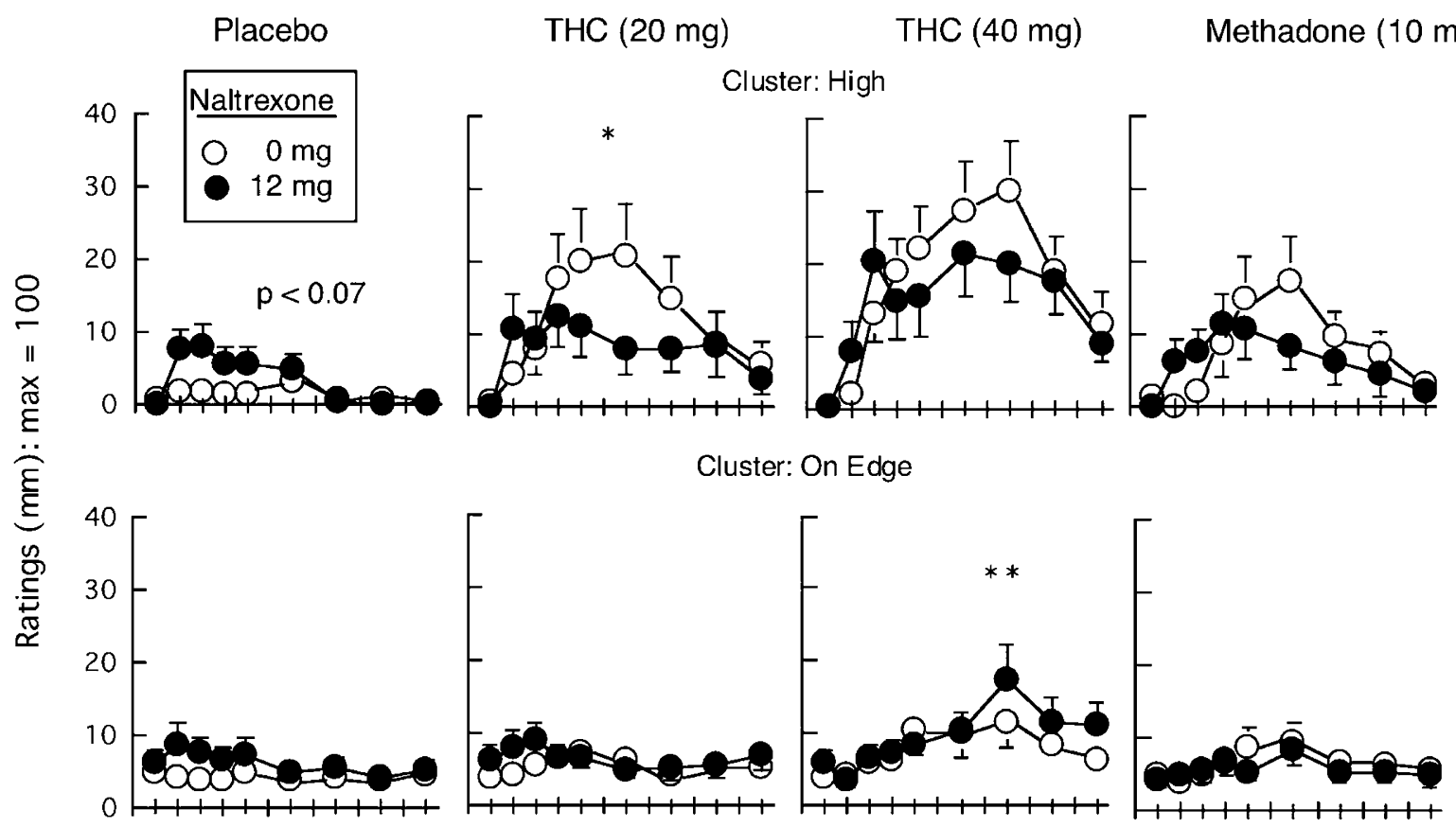

DSST: Total Correct

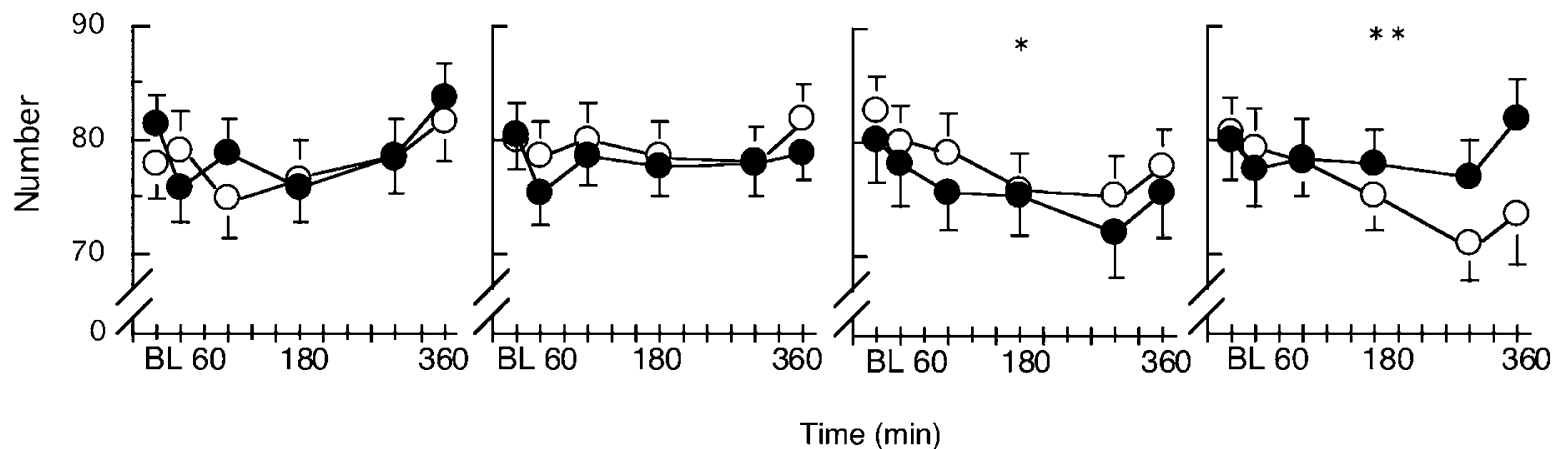

Figure 2 Time course for selected subjective-effects ratings portrayed as a function of THC, methadone, and naltrexone dose in Study I (marijuana smokers). Asterisks denote a significant difference between active and placebo naltrexone for each dose condition for data averaged over 30-360 min following THC or methadone administration (*p<0.05; **p $<0.0 \mathrm{I}$ ). Error bars represent standard error of the mean (SEM).

By contrast, methadone time-dependently decreased performance on the DSST and DAT, and naltrexone significantly reversed these effects (Figure 2, Table 2; $p<0.01)$. Specifically, accuracy tracking a moving target (Track Distance), as well as latency to respond to a signal while tracking the moving target (Hit Latency), was significantly improved when naltrexone preceded methadone administration.

Word recall/recognition task. There was no significant effect of placebo, THC, or methadone on measures of word recall and recognition.

Side effects. Table 3 portrays the number of marijuana smokers who experienced side effects from the capsules. THC produced few side effects in this population of current marijuana smokers. The majority of symptoms reflect nausea and stomach upset following methadone administration under placebo naltrexone conditions. Naltrexone reversed methadone's side effects.
Cardiovascular effects. Table 2 demonstrates that naltrexone alone significantly $(p<0.01)$ decreased heart-rate. THC dose-dependently increased heart rate, and naltrexone significantly antagonized this effect for each THC dose $(p<0.01)$. Methadone decreased heart rate, and naltrexone did not significantly alter this effect.

\section{METHODS}

\section{Study 2: Nonmarijuana Smokers}

Participants. The objective of Study 2 was to replicate the procedures of Study 1 in nonmarijuana smokers with no history of daily marijuana use. Table 1 portrays the demographic characteristics of the healthy male $(n=11)$ and female $(n=10)$ research volunteers who participated in the study. Two additional male volunteers and four additional female volunteers began but discontinued the study for not adhering to protocol $(n=2)$, because they did 
Table 2 Selected Mean ( \pm SEM) Subjective-Effects, Psychomotor Task Performance, and Heart-Rate as a Function of Placebo, THC, and Methadone Dose in Marijuana Smokers (Study I)

THC

\begin{tabular}{|c|c|c|c|c|}
\hline Naltrexone & Placebo & $20 \mathrm{mg}$ & $40 \mathrm{mg}$ & Methadone $10 \mathrm{mg}$ \\
\hline \multicolumn{5}{|c|}{ Cluster: tired (mm) } \\
\hline $0 \mathrm{mg}$ & $8.5(1.0)$ & $10.4(0.9)$ & |3.4 (1.4) & $10.8(0.9)$ \\
\hline $12 \mathrm{mg}$ & | $1.3(0.9)^{*}$ & $12.2(1.2)$ & $17.9(1.5)^{* * *}$ & | $3.0(1.3)^{*}$ \\
\hline \multicolumn{5}{|c|}{ Digit: immediate recall (\#) } \\
\hline $0 \mathrm{mg}$ & $6.66(0.18)$ & $6.24(0.20)$ & $6.34(0.18)$ & $6.41(0.17)$ \\
\hline $12 \mathrm{mg}$ & $6.57(0.19)$ & $6.21(0.20)$ & $5.93(0.27)^{* * *}$ & $6.57(0.18)$ \\
\hline \multicolumn{5}{|c|}{ DAT: track distance (pixels) } \\
\hline $0 \mathrm{mg}$ & I $3682(970)$ & I 3789 (728) & |367| (778) & | $4920(965)$ \\
\hline $12 \mathrm{mg}$ & $12686(595)$ & $12396(517)$ & $13430(9 \mid 2)$ & $12324(5 \mid 4)^{* * *}$ \\
\hline \multicolumn{5}{|c|}{ DAT: hit latency (tics) } \\
\hline $0 \mathrm{mg}$ & $1313(55)$ & $1383(68)$ & $1280(53)$ & $1399(67)$ \\
\hline $12 \mathrm{mg}$ & $1326(60)$ & $1256(49)$ & | $402(74)^{*}$ & $1269(45)^{*}$ \\
\hline \multicolumn{5}{|c|}{ Heart rate (b.p.m.) } \\
\hline $0 \mathrm{mg}$ & $65.3(0.8)$ & $66.6(0.9)$ & $71.3(1.1)$ & $61.1(0.7)$ \\
\hline $12 \mathrm{mg}$ & $63.2(0.7)^{*}$ & $64.8(0.9)^{*}$ & $67.2(0.9)^{* * *}$ & $62.9(0.7)$ \\
\hline
\end{tabular}

Note: Mean data obtained 30-360 min following capsule administration. Subjective-effects ratings ranged from 0 to $100 \mathrm{~mm}$. Asterisks indicate a significant difference between placebo and active naltrexone for each dose condition: $* 00.05$, $* * * 0.01$.

not like the medication effects $(n=3)$, or because the capsules were not kosher $(n=1)$.

Design and procedures. Experimental procedures and data analysis were identical to those used in Study 1, except that (1) three rather than two active doses of THC were tested since we did not have preliminary data on the THC doserange appropriate for nonmarijuana smokers; thus, there were 10 rather than eight experimental sessions completed over 4-6 weeks, and (2) the doses of $\operatorname{THC}(0,2.5,5,10 \mathrm{mg})$ and methadone $(7.5 \mathrm{mg})$ were lower since the volunteers were not tolerant to cannabinoids and were uncomfortable with strong drug effects; initially a higher THC dose range $(5,10,15 \mathrm{mg})$ was tested in two participants, but the highest THC dose produced an uncomfortable level of intoxication.

Data analysis. Similar to Study 1, there were three withingroup factors (medication (placebo, $2.5 \mathrm{mg}$ THC, $5.0 \mathrm{mg}$ THC, $10.0 \mathrm{mg}$ THC, $7.5 \mathrm{mg}$ methadone), naltrexone dose $(0,12 \mathrm{mg})$, and time within session (baseline measures through $360 \mathrm{~min})$ ). Five planned comparisons were completed for each measure: time course data collected following capsule administration were averaged, and a comparison between the active and placebo naltrexone pretreatment condition was made for each medication condition. There was no significant interaction between sex and naltrexone

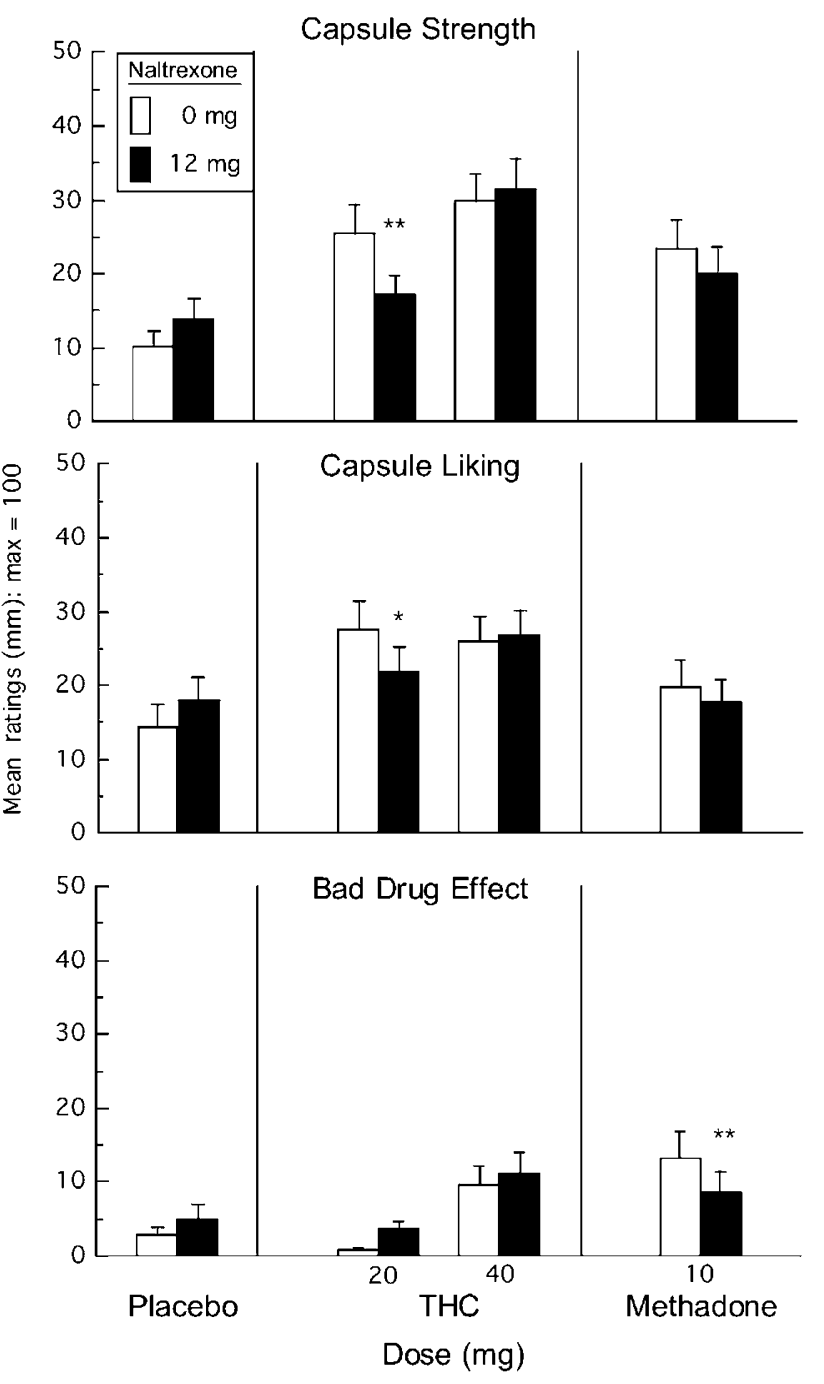

Figure 3 Selected Capsule Rating Form data portrayed as a function of THC, methadone, and naltrexone dose condition in Study I (marijuana smokers). Asterisks denote a significant difference between active and placebo naltrexone for each dose condition for data averaged over 90-180 min following THC or methadone administration ( $P<<0.05$; ** $p<0.0$ I). Error bars represent standard error of the mean (SEM).

dose, or the combination of sex, medication, and naltrexone dose for any measure, so data from male and female participants were combined. The interaction between medication and sex approached significance $(p<0.10)$ and are portrayed below for illustrative purposes. Huynh-Feldt corrections were used, when appropriate. $p$-Values less than 0.05 were considered statistically significant.

\section{RESULTS}

\section{Nonmarijuana Smokers}

Demographic characteristics. Demographic characteristics in nonmarijuana smokers did not significantly vary as a function of sex.

Pupil diameter. Methadone $(7.5 \mathrm{mg})$ produced small but time-dependent decreases in pupil diameter (baseline: 
$4.5 \mathrm{~mm}$; $240 \mathrm{~min}$ postmethadone: $3.8 \mathrm{~mm}$ ). Naltrexone $(12 \mathrm{mg})$ showed a trend in reversing these effects $(p<0.06)$.

Subjective-effects ratings. Figure 4, which compares the effects of placebo, THC, and methadone as a function of sex and time within session, demonstrates that under placebo naltrexone conditions, men were more sensitive to the effects of THC than women.

Figure 5 and Table 4 demonstrate that naltrexone had no significant intrinsic effects in nonmarijuana smokers. THC produced time-and dose-dependent effects on ratings

Table 3 Number of Participants in Marijuana Smokers (Study I) Experiencing Side Effects as a Function of Medication Condition $(\max =22)$

\begin{tabular}{|c|c|c|c|c|}
\hline \multirow[b]{2}{*}{ Naltrexone } & \multirow[b]{2}{*}{ Placebo } & \multicolumn{2}{|c|}{ THC } & \multirow[b]{2}{*}{ Methadone $10 \mathrm{mg}$} \\
\hline & & $20 \mathrm{mg}$ & $40 \mathrm{mg}$ & \\
\hline \multicolumn{5}{|c|}{ Nausea/vomiting } \\
\hline $0 \mathrm{mg}$ & 0 & 0 & I & 7 \\
\hline $12 \mathrm{mg}$ & 0 & 0 & 0 & 0 \\
\hline \multicolumn{5}{|l|}{ Stomach ache } \\
\hline $0 \mathrm{mg}$ & 0 & । & 0 & 2 \\
\hline $12 \mathrm{mg}$ & 0 & I & 2 & 0 \\
\hline \multicolumn{5}{|l|}{ Itchy skin } \\
\hline $0 \mathrm{mg}$ & 0 & 0 & 0 & I \\
\hline $12 \mathrm{mg}$ & 0 & 0 & 0 & 0 \\
\hline \multicolumn{5}{|c|}{ Dizzy/lightheaded } \\
\hline $0 \mathrm{mg}$ & 0 & 0 & 2 & I \\
\hline $12 \mathrm{mg}$ & I & । & 2 & 0 \\
\hline \multicolumn{5}{|l|}{ Headache } \\
\hline $0 \mathrm{mg}$ & 0 & 0 & 0 & 0 \\
\hline $12 \mathrm{mg}$ & 0 & 0 & I & I \\
\hline
\end{tabular}

of 'high,' 'on edge,' and 'tired.' Naltrexone significantly increased ratings of 'high' following a low THC dose (Figure 5; $2.5 \mathrm{mg}$ ), while increasing ratings of 'tired' following both the low and high dose of THC (Table 4; $2.5,10 \mathrm{mg}$ ). Naltrexone also decreased ratings of 'on edge' at the high THC dose (Figure 5; $10 \mathrm{mg}$ ). Methadone increased ratings of 'high,' and naltrexone did not significantly alter this effect.

Capsule Rating Form. Figure 6, which portrays mean capsule ratings, shows that naltrexone alone decreased ratings of capsule liking. THC produced dose-dependent increases in capsule strength and bad drug effect. Naltrexone significantly altered a range of effects for the low THC dose $(2.5 \mathrm{mg})$ : increasing both ratings of capsule strength and bad drug effect, while decreasing ratings of liking $(p<0.05)$. Methadone increased ratings of capsule strength and bad drug effect, and naltrexone reversed this effect for both ratings $(p<0.05)$.

Performance effects. Figure 5 and Table 4 demonstrate that naltrexone alone did not alter task performance, and THC did not have dose- or time-dependent effects on task performance. However, naltrexone pretreatment worsened performance on the DSST (Figure 5), Digit Recall and DAT following the low dose of THC (Table 4; $2.5 \mathrm{mg}$ ). Naltrexone improved the effects of a higher THC dose $(5 \mathrm{mg})$ on the DAT (Track Distance) compared to placebo (Table 4).

Methadone worsened performance on the DSST, Digit Recall, and DAT, and naltrexone reversed these effects. Specifically, naltrexone administration prior to methadone improved performance on the DSST task (Figure 5), Digit Recall and the DAT (Table 2), in terms of both accuracy tracking a moving target (Track Distance) as well as latency to respond to a signal while tracking the moving target (Hit Latency).

Cardiovascular effects. Table 4 demonstrates that naltrexone alone significantly decreased heart rate $(p<0.05)$. THC dose-dependently increased heart rate, and naltrexone significantly reversed this effect at each THC dose $(p<0.05)$. Methadone decreased heart rate, and naltrexone did not significantly alter this effect. 
Placebo

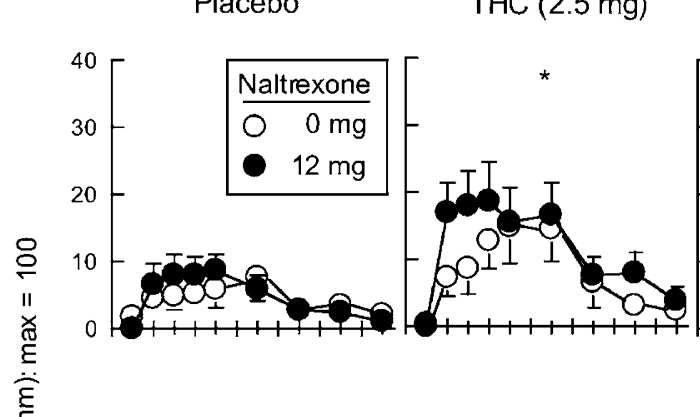

THC (5.0 mg)

THC (10.0)

Methadone $(7.5 \mathrm{mg})$
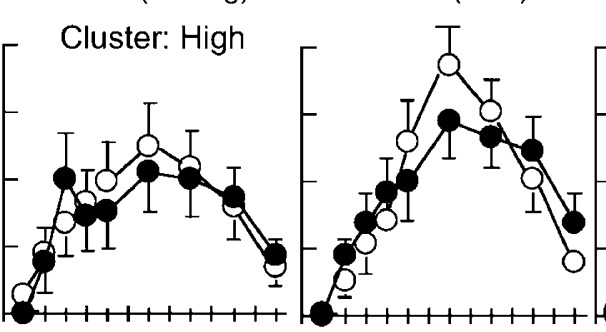

Cluster: On Edge
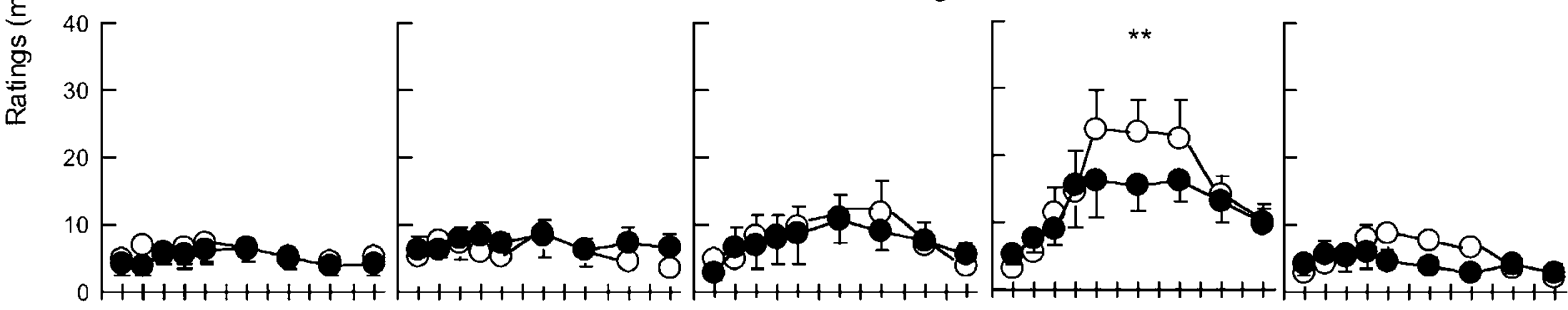

DSST: Total Correct

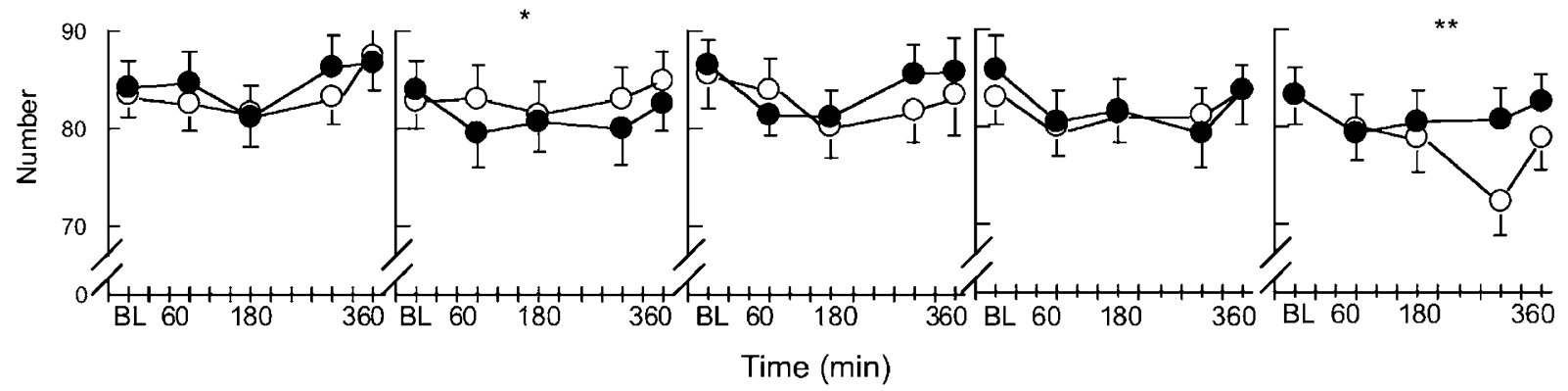

Figure 5 Time course for selected subjective-effects ratings portrayed as a function of THC, methadone, and naltrexone dose in Study 2 (nonmarijuana smokers). See Figure 2 legend for details.

Word recall/recognition task. Following placebo pretreatment, neither THC nor methadone altered word recall and recognition, and there was no significant effect of naltrexone on these measures.

Side effects. Table 5 portrays the number of nonmarijuana smokers who experienced side effects from the capsules. As in Study 1, nausea and stomach upset following methadone administration were reversed by naltrexone. The highest dose of THC $(10 \mathrm{mg})$ produced side effects in more participants than the other medication conditions: nausea, dizziness, lightheadedness, and overintoxication. Naltrexone did not reverse the effects of THC. In fact, naltrexone increased the number of participants reporting nausea after THC (10 mg) administration.

\section{DISCUSSION}

We have previously reported that a clinically utilized dose of naltrexone $(50 \mathrm{mg})$ increased the intoxicating effects of THC in a population of predominantly male marijuana smokers (Haney et al, 2003). This enhancement of cannabinoid effects contrasted with data from laboratory animals showing that cannabinoid effects are attenuated by opioid antagonists. Thus, the objective of Study 1 was to test a lower, more opioid-selective dose of naltrexone $(12 \mathrm{mg})$ in combination with THC in male and female marijuana smokers. The results show that low-dose naltrexone attenuated ratings of 'high,' capsule strength and capsule liking following $20 \mathrm{mg}$ THC. At the higher THC dose $(40 \mathrm{mg})$, naltrexone pretreatment significantly increased ratings of 'on edge' and 'tired,' and worsened performance on computer tasks assessing attention, visual scanning, and memory. Naltrexone's effects on ratings of 'tired' were not specific to THC, as ratings were also increased following placebo or methadone administration.

The effects of methadone, which was tested as a positive control, were antagonized by low-dose naltrexone: naltrexone reversed methadone-induced miosis, ratings of bad drug effect, side effects, and disruptions in task performance. Increased ratings of 'high' following methadone were not reversed by low-dose naltrexone. Yet, naltrexone alone increased ratings of 'tired' and produced peak ratings of 'high' 30-60 min postcapsule administration in marijuana smokers. These intrinsic effects peaking early in the session may account for the nonsignificant effects of naltrexone.

Thus, the first conclusion from Study 1 is that low-dose naltrexone $(12 \mathrm{mg})$ blunted THC's intoxicating effects in marijuana smokers. The robust enhancement in THC's effects observed in marijuana smokers following pretreatment with a high dose of naltrexone $(50 \mathrm{mg}$; Haney et al, 2003) did not occur, suggesting that this enhancement was 
Table 4 Selected Mean ( \pm SEM) Subjective-Effects, Psychomotor Task Performance, and Heart-Rate as a Function of Placebo, THC, and Methadone Dose in Nonmarijuana Smokers (Study 2)

\begin{tabular}{|c|c|c|c|c|c|}
\hline \multirow[b]{2}{*}{ Naltrexone } & \multirow[b]{2}{*}{ Placebo } & \multicolumn{3}{|c|}{ THC } & \multirow[b]{2}{*}{ Methadone $7.5 \mathrm{mg}$} \\
\hline & & $2.5 \mathrm{mg}$ & $5 \mathrm{mg}$ & $10 \mathrm{mg}$ & \\
\hline $0 \mathrm{mg}$ & $10.0(1.0)$ & $9.2(1.0)$ & $16.0(1.4)$ & $19.7(1.5)$ & $10.6(1.2)$ \\
\hline $12 \mathrm{mg}$ & I0.1 (0.9) & $14.8(1.2) * *$ & | $8.2(1.6)$ & $24.8(1.6)^{* * *}$ & $8.5(0.9)$ \\
\hline $0 \mathrm{mg}$ & $7.02(0.13)$ & $6.86(0.16)$ & $6.69(0.15)$ & $6.89(0.14)$ & $6.13(0.17)$ \\
\hline $12 \mathrm{mg}$ & $6.80(0.14)$ & $6.31(0.19)^{* * *}$ & $7.00(0.12)$ & $6.45(0.16)$ & $6.83(0.14)^{* * *}$ \\
\hline \multicolumn{6}{|c|}{ DAT: track distance (pixels) } \\
\hline $0 \mathrm{mg}$ & $8984(4 \mid 4)$ & $9704(475)$ & 13003 (1319) & I0724 (749) & I $6833(254 \mid)$ \\
\hline $0 \mathrm{mg}$ & II37 (35) & $1228(39)$ & $1338(64)$ & $1237(46)$ & $1604(120)$ \\
\hline $12 \mathrm{mg}$ & I I 37 (34) & $1454(93)^{*}$ & $1289(49)$ & $1366(76)$ & $1257(48) * *$ \\
\hline \multicolumn{6}{|c|}{ Heart rate (b.p.m.) } \\
\hline $0 \mathrm{mg}$ & $69.4(0.7)$ & $71.5(0.7)$ & $72.3(1.0)$ & $73.9(1.0)$ & $66.6(0.7)$ \\
\hline $12 \mathrm{mg}$ & $67.0(0.7)^{* * *}$ & $69.7(0.8)^{*}$ & $68.7(0.8)^{* * *}$ & $71.9(1.0)^{*}$ & $66.3(0.7)$ \\
\hline
\end{tabular}

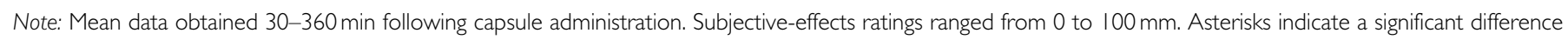
between placebo and active naltrexone for each dose condition: $* p<0.05$, $* * p<0.01$.

not due to opioid blockade, but reflected the nonopioid effects of high dose naltrexone.

The blunting of THC's intoxicating effects by naltrexone is consistent with the decrease in THC's discriminativestimulus and reinforcing effects observed in laboratory animals (see Introduction). Naltrexone's blunting of the 'high' and capsule liking occurred at the lower but not the higher dose of THC. At the higher THC dose, naltrexone increased anxiety, and worsened performance on computer tasks. Similarly, the data in laboratory animals do not demonstrate that opioid antagonists fully block cannabinoid effects (as do CB1 antagonists: eg, Wiley et al, 1995; Tanda et al, 2000). Cannabinoid effects depend on the relative contribution of several neurotransmitters: GABA, endogenous opioids, and glutamate (Lupica et al, 2004). In rodents, THC increases endogenous opioid peptide release in the VTA, and this effect contributes to THC's discriminative-stimulus properties; opioid agonists in the VTA potentiate the effects of low doses of THC to increase THC discrimination, while opioid antagonists block the effects of endogenous opioids and decrease THC discrimination (Solinas et al, 2004b; Solinas and Goldberg, 2005; Valverde et al, 2001). In marijuana smokers, naltrexone altered the profile of THC's subjective-effects, supporting the idea that opioid peptides contribute to but do not mediate cannabinoid subjective-effects.

Given the preclinical evidence that chronic cannabinoid exposure alters opioid binding and synthesis, the objective of Study 2 was to determine the interaction between low- dose naltrexone, THC, and methadone in men and women with no history of daily marijuana use. The THC doses administered in nonmarijuana smokers were approximately fourfold lower than those used in marijuana smokers since the participants in Study 2 were not tolerant to the effects of cannabinoids; however, the magnitude of effects was comparable between the two studies.

The results show that low-dose naltrexone shifted THC's effects in an opposite direction in nonmarijuana smokers compared to marijuana smokers. Rather than blunting THC's effects, naltrexone increased ratings of 'high,' capsule strength, and bad drug effect, while decreasing ratings of capsule liking following a low dose of THC $(2.5 \mathrm{mg})$; note that this enhancement by naltrexone was small relative to what occurred with $50 \mathrm{mg}$ dose of naltrexone in marijuana smokers (Haney et al, 2003). At a higher THC dose (10 mg), naltrexone decreased ratings of anxiety. THC also produced a range of side effects in this population of nondrug users, and naltrexone tended to worsen these effects rather than attenuate them. By contrast, adverse effects from methadone were fully reversed by naltrexone.

Although the nonmarijuana smokers were hypothesized to show a pattern of effects that paralleled laboratory animals because neither group was chronically exposed to cannabinoids, it was the chronic marijuana smokers who showed a blunted effect. The mechanism for a small but significant enhancement in THC's intoxicating effects is not clear. Human in vitro data show that $\mathrm{CB} 1$ receptors sequester G-proteins from a common pool, preventing 


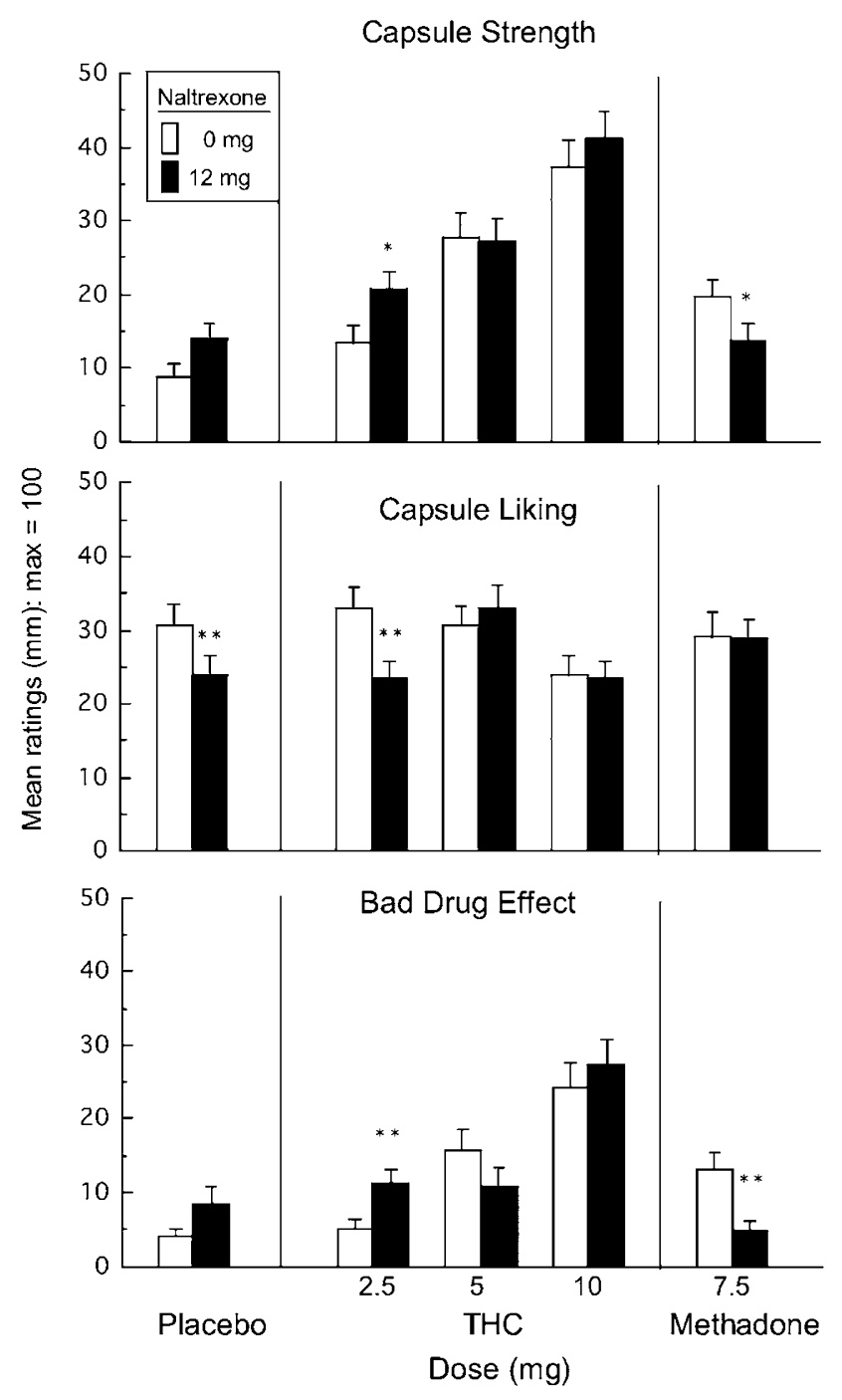

Figure 6 Selected Capsule Rating Form data portrayed as a function of THC, methadone, and naltrexone dose in Study 2 (nonmarijuana smokers). See Figure 3 legend for details.

action by other G-protein linked receptors (Vásquez and Lewis, 1999). If opioids and cannabinoids colocalized on the same neurons compete for the same pool of G-proteins (see Romero et al, 1998), it is feasible that blocking the opioid receptor could increase cannabinoid effects.

The fact that the direction in which low-dose naltrexone interacted with THC differed in marijuana smokers and nonmarijuana smokers suggests that chronic marijuana use alters the interaction between opioids and cannabinoids in humans. CB1 and mu opioid receptors are closely interrelated in the ventral striatum, often localized on the same neuron or on synaptically-linked neurons (Hoffman and Lupica, 2001; Pickel et al, 2004). As reviewed in the Introduction, data from laboratory animals demonstrate that chronic cannabinoid exposure decreases CB1-mediated activity while increasing opioid synthesis, receptor activity, and behavioral effects. It may be that the different pattern of results observed in marijuana-smoking and nonsmoking participants reflects an altered balance of cannabinoid and opioid activity subsequent to chronic marijuana use.
Table 5 Number of Nonmarijuana Smokers (Study 2) Experiencing Side Effects as a Function of Medication Condition $(\max =2 \mathrm{l})$

\begin{tabular}{|c|c|c|c|c|c|}
\hline \multirow[b]{2}{*}{ Naltrexone } & \multirow[b]{2}{*}{ Placebo } & \multicolumn{3}{|c|}{ THC } & \multirow[b]{2}{*}{ Methadone $7.5 \mathrm{mg}$} \\
\hline & & $2.5 \mathrm{mg}$ & $5 \mathrm{mg}$ & $10 \mathrm{mg}$ & \\
\hline \multicolumn{6}{|c|}{ Nausea/vomiting } \\
\hline $0 \mathrm{mg}$ & 0 & 0 & । & । & 4 \\
\hline $12 \mathrm{mg}$ & 1 & 0 & I & 4 & । \\
\hline \multicolumn{6}{|l|}{ Stomach ache } \\
\hline $0 \mathrm{mg}$ & I & 0 & । & 0 & 0 \\
\hline $12 \mathrm{mg}$ & 0 & I & 0 & 0 & 0 \\
\hline \multicolumn{6}{|c|}{ Dizzy/lightheaded } \\
\hline $0 \mathrm{mg}$ & I & 0 & 2 & 2 & । \\
\hline $12 \mathrm{mg}$ & 0 & 2 & 3 & 3 & । \\
\hline \multicolumn{6}{|l|}{ Headache } \\
\hline $0 \mathrm{mg}$ & । & 0 & 0 & । & 0 \\
\hline $12 \mathrm{mg}$ & I & 0 & 0 & 0 & 0 \\
\hline \multicolumn{6}{|l|}{ Paranoid } \\
\hline $0 \mathrm{mg}$ & 0 & 0 & । & 0 & 0 \\
\hline $12 \mathrm{mg}$ & 0 & 0 & 0 & 2 & 0 \\
\hline \multicolumn{6}{|l|}{ Overintoxicated } \\
\hline $0 \mathrm{mg}$ & 0 & 0 & । & 5 & 0 \\
\hline $12 \mathrm{mg}$ & 0 & 0 & 0 & 4 & । \\
\hline
\end{tabular}

However, since we do not have data from the marijuana smokers before their onset of heavy marijuana use, an alternative explanation is that naltrexone's divergent effects are due to factors unrelated to marijuana use, for example, lifestyle or genetic differences between these populations.

An objective of both studies was to determine the influence of sex on the interaction between naltrexone and THC. There was little indication that sex significantly influenced this interaction, although there were sex differences in response to THC alone. Nonmarijuana smoking men were more sensitive to the effects of THC than nonmarijuana smoking women, consistent with differences observed with smoked marijuana (Penetar et al, 2005). Menstrual cycle phase has not been shown to modulate marijuana's subjective or cardiovascular effects (Lex et al, 1984). Further, men and women do not appear to differ in the metabolism of THC (Wall et al, 1983). Rather, it is likely that sex differences in cannabinoid effects are related to body fat distribution. THC is lipophilic, and women have a higher percentage of body fat than men, suggesting women had less of an effect because more THC was absorbed by fat cells. In parallel, male rodents have a higher percentage of body fat and a lower behavioral response to cannabinoids than females (Tseng and Craft, 2004; Wiley, 2003). In the marijuana-smoking group, men 
smoked twice as much marijuana as women, which may have obviated any sex difference, that is, men were likely to be more tolerant to marijuana than women.

Finally, although withdrawal was not studied directly, there was no evidence that naltrexone precipitated cannabinoid withdrawal in near-daily marijuana smokers, consistent with our earlier report (Haney et al, 2003): Cluster ratings of 'bad effect' and 'miserable' were negligible when active naltrexone was combined with placebo. Naltrexone had intrinsic effects, such as decreasing heart rate in all participants, increasing ratings of fatigue and 'high' in marijuana smokers, and decreasing capsule liking in nonmarijuana smokers. Yet, this pattern is not consistent with symptoms of marijuana withdrawal (Haney et al, 1999).

\section{Conclusions}

A low, opioid-specific dose of naltrexone modulated the effects of THC in humans, but the direction of this influence varied as a function of marijuana use history. In marijuana smokers, naltrexone blunted THC intoxication, while in nonmarijuana smokers, naltrexone enhanced THC intoxication. These shifts were largely limited to one dose of THC. Yet, the fact that naltrexone only blunted THC's intoxicating effects in marijuana smokers suggests that chronic marijuana use increases the opioid contribution to cannabinoid intoxication.

\section{Future Studies}

A study testing a range of naltrexone doses in combination with smoked marijuana would address a number of questions arising from the present findings: (1) Does a blunting of THC's effects in heavy marijuana smokers suggest naltrexone could have potential as treatment medication for marijuana dependence? (2) Do clinically utilized doses of naltrexone alter marijuana's intoxicating effects in patients seeking drug treatment? Naltrexone is used to treat both alcohol and opioid dependence (Anton et al, 2006; Gonzales et al, 2002), and the standard clinical doses are 50-150 mg. The present results in combination with our earlier report (Haney et al, 2003) suggest that marijuana-smoking patients treated with high naltrexone doses may experience an enhanced effect from marijuana. Low doses of naltrexone, as achieved with depot naltrexone formulations (eg, Comer et al, 2002), may decrease marijuana's effects.

\section{ACKNOWLEDGEMENTS}

This research was supported by US National Institute on Drug Abuse Grant DA09236. The exceptional assistance of Cassidy Cleavinger and Roxanne McMorris in data collection is gratefully acknowledged, as is the editorial contribution of Richard W Foltin.

\section{REFERENCES}

Anton RF, O'Malley SS, Ciraulo DA, Cisler RA, Couper D, Donovan $\mathrm{DM}$ et al (2006). Combined pharmacotherpaies and behavioral interventions for alcohol dependence. J Am Med Assoc 295: 2003-2017.

Beardsley PM, Balster RL, Harris LS (1986). Dependence on tetrahydrocannabinol in rhesus monkeys. J Pharmacol Exp Ther 239: 311-319.

Braida D, Pozzi M, Parolaro D, Sala M (2001). Intracerebral selfadministration of the cannabinoid receptor agonist CP 55940 in the rat: interaction with the opioid system. Eur J Pharmacol 413: 227-234.

Cadoni C, Pisanu A, Solinas M, Acquas E, Di Chiara G (2001). Behavioural sensitization after repeated exposure to $\Delta^{9}$-tetrahydrocannabinol and cross-sensitization with morphine. Psychopharmacology 158: 259-266.

Castãné A, Robledo P, Matifas A, Kieffer BL, Maldonado R (2003). Cannabinoid withdrawal syndrome is reduced in double mu and delta opioid receptor knockout mice. Eur J Neurosci 17: 155-159.

Casteñada E, Moss DE, Oddie SD, Whishaw IQ (1991). THC does not affect striatal dopamine release: microdialysis in freely moving rats. Pharmacol Biochem Behav 40: 587-591.

Chen J, Paredes W, Li J, Smith D, Lowinson J, Gardner EL (1990). $\Delta^{9}$-Tetrahydrocannabinol produces naloxone-blockable enhancement of presynaptic basal dopamine efflux in nucleus accumbens of conscious, freely-moving rats as measured by intracerebral microdialysis. Psychopharmacology 102: 156-162.

Chen J, Paredes W, Lowinson JH, Gardner EL (1991). Strainspecific facilitation of dopamine efflux by $\Delta^{9}$-tetrahydrocannabinol in the nucleus accumbens of rat: an in vivo microdialysis study. Neurosci Lett 129: 136-140.

Comer SD, Collins ED, Kleber HD, Nuwayser ES, Kerrigan JH, Fischman MW (2002). Depot naltrexone: long-lasting antagonism of the effects of heroin in humans. Psychopharmacology 159: 351-360.

Comer SD, Collins ED, Wilson ST, Donovan MR, Foltin RW, Fischman MW (1998). Effects of an alternative reinforcer on intravenous heroin self-administration by humans. Eur $J$ Pharmacol 345: 13-26.

Corchero J, Fuentes JA, Manzanares J (1997). $\Delta^{9}$-Tetrahydrocannabinol increases proopiomelanocortin gene expression in the arcuate nucleus of the rat hypothalamus. Eur J Pharmacol 323: 193-195.

Corchero J, Romero J, Berrendero F, Fernandez-Ruiz J, Ramos JA, Fuentes JA et al (1999). Time-dependent differences of repeated administration with $\Delta^{9}$-tetrahydrocannabinol in proenkephalin and cannabinoid receptor gene expression and G-protein activation by $\mu$-opioid and $\mathrm{CB}_{1}$-cannabinoid receptors in the caudate-putamen. Brain Res Mol Brain Res 67: 148-157.

Di Chiara G (1995). The role of dopamine in drug abuse viewed from the perspective of its role in motivation. Drug Alc Depend 38: 95-137.

Dingledine R, Iversen LL, Breuker E (1978). Naloxone as a GABA antagonist: evidence from iontophoretic, receptor binding and convulsant studies. Eur J Pharmacol 47: 19-27.

Evans SM, Haney M, Levin FR, Foltin RW, Fischman MW (1998). Mood and performance changes in women with premenstrual dysphoric disorder: acute effects of alprazolam. Neuropsychopharmacology 19: 499-516.

Evans SM, Troisi II JR, Griffiths RR (1994). Tandospirone and alprazolam: comparison of behavioral effects and abuse liability in humans. J Pharmacol Exp Ther 271: 683-694.

Foltin RW, Haney M, Comer SD, Fischman MW (1996). Effect of fluoxetine on food intake of humans living in a residential laboratory. Appetite 27: 165-181.

French ED (1997). $\Delta^{9}$-Tetrahydrocannabinol excites rat VTA dopamine neurons through activation of cannabinoid CB1 but no opioid receptors. Neurosci Lett 226: 159-162.

Gessa GL, Melis M, Muntoni AL, Diana M (1998). Cannabinoids activate mesolimbis dopamine neurons by an action on cannabinoid $\mathrm{CB}_{1}$ receptors. Eur J Pharmacol 341: 39-44. 
Gewiss MV, Marley RJ, Thorndike EB, Goldberg SR, Schindler CW (1994). GABA receptor-linked chloride channels and the behavioral effects of naltrexone in rats. Pharmacol Biochem and Behav 49: 589-597.

Gonzales G, Oliveto A, Kosten TR (2002). Treatment of heroin (diamorphine) addiction: current approaches and future prospects. Drugs 62: 1331-1343.

Greenwald MK, Stitzer ML (2000). Antinociceptive, subjective and behavioral effects of smoked marijuana in humans. Drug Alcohol Depend 59: 261-275.

Haney M, Bisaga A, Foltin RW (2003). Interaction between naltrexone and oral THC in heavy marijuana smokers. Psychopharmacology 166: 77-85.

Haney M, Ward AS, Comer SD, Foltin RW, Fischman MW (1999). Abstinence symptoms following smoked marijuana in humans. Psychopharmacology 141: 395-404.

Hirschhorn ID, Rosencrans JA (1974). Morphine and $\Delta^{9}$-tetrahydrocannabinol: tolerance to the stimulus effects. Psychopharmacologia 36: 243-253.

Hoffman AF, Lupica CR (2001). Direct actions of cannabinoids on synaptic transmission in the nucleus accumbens: a comparison with opioids. J Neurophysiol 85: 72-83.

Justinova Z, Tanda G, Munzar P, Goldberg S (2004). The opioid antagonist naltrexone reduces the reinforcing effects of $\Delta^{9}$ tetrahydrocannabinol (THC) in squirrel monkeys. Psychopharmacology 173: 186-194.

Kaymakcalan S, Ayhan IH, Tulunay FC (1977). Naloxone-induced or postwithdrawal abstinence signs in $\Delta^{9}$-tetrahydrocannabinoltolerant rats. Psychopharmacology 55: 243-249.

Lamarque S, Taghzouti K, Simon H (2001). Chronic treatment with $\Delta \Delta^{9}$-tetrahydrocannabinol enhances the locomotor response to amphetamine and heroin. Implications for vulnerability to drug addiction. Neuropharmacology 41: 118-129.

Lex BW, Mendelson JH, Bavli S, Harvey K, Mello NK (1984). Effects of acute marijuana smoking on pulse rate and mood states in women. Psychopharmacology 84: 178-187.

Lichtman AH, Sheikh SM, Loh HH, Martin BR (2001). Opioid and cannabinioid modulation of precipitated withdrawal in $\Delta^{9}$ tetrahydrocannabinol and morphine-dependent mice. J Pharmacol Exp Ther 298: 1007-1014.

Lupica CR, Riegel AC, Hoffman AF (2004). Marijuana and cannabinoid regulation of brain reward circuits. Br J Pharmacol 143: $227-234$.

Manzanares J, Corchero J, Romero J, Fernandez-Ruiz JJ, Ramos JA, Fuentes JA (1998). Chronic administration of cannabinoids regulates proenkephalin mRNA levels in selected regions of the rat brain. Mol Brain Res 55: 126-132.

Manzanares J, Corchero J, Romero J, Fernandez-Ruiz JJ, Ramos JA, Fuentes JA (1999). Pharmacological and biochemical interactions between opioids and cannabinoids. Trends Pharmacol Sci 20: 287-294.

Martin BR, Sim-Selley LJ, Selley DE (2004). Signaling pathways involved in the development of cannabinoid tolerance. Trends Pharmacol Sci 25: 325-330.

Mason DJ, Lowe J, Welch SP (1999). A diminution of $\Delta^{9}$ tetrahydrocannabinol modulation of dynorphin A-(1-17) in conjunction with tolerance development. Eur J Pharmacol 381: $105-111$.

McMillan DE, Dewey WL, Harris LS (1971). Characteristics of tetrahydrocannabinol tolerance. Ann NY Acad Sci 191: 83-99.

Navarro M, Carrera MRA, Fratta W, Valverde O, Cossu G, Fattore $\mathrm{L}$ et al (2001). Functional interaction between opioid and cannabinoid receptors in drug self-administration. J Neurosci 21: 5344-5350.

Navarro M, Chowen J, Carrera MRA, del Arco I, Villanúa MA, Martin Y et al (1998). CB1 cannabinoid receptor antagonistinduced opiate withdrawal in morphine-dependent rats. Neuro Report 9: 3397-3402.
Norwood CS, Cornish JL, Mallet PE, McGregor IS (2003). Preexposure to the cannabinoid receptor agonist CP 55940 enhances morphine behavioral sensitization and alters morphine selfadministration in Lewis rats. Eur J Pharmacol 465: 105-114.

Penetar DM, Kouri EM, Gross MM, McCarthy EM, Thee CK, Peters EN et al (2005). Transdermal nicotine alters some of marihuana's effects in male and females volunteers. Drug Alcohol Depend 79: 211-223.

Pickel VM, Chan J, Kash TL, Rodríguez JJ, Makie K (2004). Compartment-specific localization of cannabinoid 1 (CB1) and $\mu$-opioid receptors in rat nucleus accumbens. Neuroscience 127: 101-112.

Romero J, Fernández-Ruiz JJ, Vela G, Ruiz-Gayo M, Fuentes JA, Ramos JA (1998). Autoradiographic analysis of cannabinoid receptor binding and cannabinoid agonist-stimulated $\left[{ }^{35} \mathrm{~S}\right] \mathrm{GTP} y \mathrm{~S}$ binding in morphine-dependent mice. Drug Alcohol Depend 50: 241-249.

Sim LJ, Hampson RE, Deadwyler SA, Childers SR (1996b). Effects of chronic treatment with $\Delta^{9}$-tetrahydrocannabinol on cannabinoid-stimulated $\left[{ }^{35} \mathrm{~S}\right] \mathrm{GTP} \gamma \mathrm{S}$ autoradiography in rat brain. J Neurosci 16: 8057-8066.

Sim LJ, Selley DE, Dworkin SI, Childers SR (1996a). Effects of chronic morphine administration on $\mu$ opioid receptor-stimulated $\left[{ }^{35} \mathrm{~S}\right] \mathrm{GTP} \gamma \mathrm{S}$ autoradiography in rat brain. J Neurosci 16: 2684-2692.

Solinas M, Goldberg SR (2005). Involvement of mu-, delta- and kappa-opioid receptor subtypes in the discriminative-stimulus effects of delta-9-tetrahydrocannabinol (THC) in rats. Psychopharmacology 179: 804-812.

Solinas M, Panililio LV, Goldberg SR (2004a). Exposure to $\Delta^{9}$ tetrahydrocannabinol (THC) increases subsequent heroin taking but not heroin's reinforcing efficacy: a self-administration study in rats. Neuropsychopharmacology 29: 1301-1311.

Solinas M, Zangen A, Thiriet N, Goldberg SR (2004b). $\beta$-Endorphin elevations in the ventral tegmental area regulate the discriminative effects of $\Delta^{9}$-tetrahydrocannabinol. E J Neurosci 19: 3183-3192.

Spano MS, Fattore L, Cossu G, Deiana S, Fadda P, Fratta W (2004). $\mathrm{CB} 1$ receptor agonist and heroin, but not cocaine, reinstate cannabinoid-seeking behaviour in the rat. $\mathrm{Br} J$ Pharmacol 143: 343-350.

Svensson AI, Berntsson A, Eirefelt M, Söderpalm B (2000). Naloxone antagonizes GABAA/benzodiazepine receptor function in rat corticohippocampal synatoneurosomes. J Neural Transm 107: $261-270$.

Tanda G, Munzar P, Goldberg SR (2000). Self-administration behavior is maintained by the psychoactive ingredient of marijuana in squirrel monkeys. Nature Neurosci 3: 1073-1074.

Tanda G, Pontieri FE, DiChiara G (1997). Cannabinoid and heroin activation of mesolimbic dopamine transmission by a common $\mu_{1}$-opioid receptor mechanism. Science 276: 2048-2050.

Tseng AH, Craft RM (2004). $\mathrm{CB}_{1}$ receptor mediation of cannabinoid behavioral effects in male and female rats. Psychopharmacology 172: 25-30.

Tulunay FC, Ayhan IH, Portoghese PS, Takemori AE (1981). Antagonism by chlornaltrexamine of some effects of $\Delta^{9}$ tetrahydrocannabinol in rats. Eur J Pharmacol 70: 219-224.

Valverde O, Maldonado R, Valjent E, Zimmer AM, Zimmer A (2000). Cannabinoid withdrawal syndrome is reduced in preproenkephalin knock-out mice. J Neurosci 20: 9284-9289.

Valverde O, Noble F, Beslot F, Dauge V, Fournie-Zaluski MC, Roques BP (2001). $\Delta^{9}$-tetrahydrocannabinol releases and facilitates the effects of endogenous enkephalins: reduction in morphine withdrawal syndrome without change in rewarding effect. Eur J Neurosci 13: 1816-1824.

Vásquez C, Lewis DK (1999). The CB1 cannabinoid receptor can sequester G-proteins, making them unavailable to couple to other receptors. J Neurosci 19: 9271-9280. 
Viganò D, Rubino T, Vaccani A, Bianchessi S, Marmorato P, Castiglioni C et al (2005). Molecular mechanisms involved in the asymmetric interaction between cannabinoid and opioid systems. Psychopharmacology 182: 527-536.

Wachtel SR, de Wit H (2000). Naltrexone does not block the subjective effects of oral $\Delta^{9}$-tetrahydrocannabinol in humans. Drug Alcohol Depend 59: 251-260.

Wall ME, Brine DR, Perez-Reyes M (1981). Metabolism and disposition of naltrexone in man after oral and intravenous administration. Drug Metab Disposition 5: 369-375.

Wall ME, Sadler BM, Brine D, Taylor H, Perez-Reyes M (1983). Metabolism, disposition, and kinetics of delta-9-tetra- hydrocannabinol in men and women. Clin Pharmacol Ther 34: 352-363.

Walsh SL, Sullivan JT, Preston KL, Garner JE, Bigelow GE (1996). Effects of naltrexone on response to intravenous cocaine, hydromorphone and their combination in humans. J Pharmacol Exp Ther 279: 524-538.

Wiley JL (2003). Sex-dependent effect of $\Delta^{9}$-tetrahydrocannabinol on locomotor activity in mice. Neurosci Lett 352: 77-80.

Wiley JL, Lowe JA, Balster RL, Martin BR (1995). Antagonism of the discriminative stimulus effects of delta 9-tetrahydrocannabinol in rats and rhesus monkeys. J Pharmacol Exp Ther 275: $1-6$. 